\title{
Comparative Nutritional Analysis of Tylosema esculentum (Marama Bean) Germplasm Collection in Namibia
}

\author{
Paidamoyo Natasha Mataranyika1, Percy Maruwa Chimwamurombe ${ }^{1, ~ *, ~ B u h l e b e n k o s i ~ F u y a n e ~}{ }^{2}$, \\ Kayini Chigayo $^{3}$, Julien Lusilao ${ }^{1}$ \\ ${ }^{1}$ Department of Natural and Applied Sciences, Namibia University of Science and Technology, Windhoek, Namibia \\ ${ }^{2}$ Department of Health Sciences, Namibia University of Science and Technology, Windhoek, Namibia \\ ${ }^{3}$ Department of Mining and Process Engineering, Namibia University of Science and Technology, Windhoek, Namibia
}

Email address:

pchimwamurombe@nust.na (P. M. Chimwamurombe)

*Corresponding author

\section{To cite this article:}

Paidamoyo Natasha Mataranyika, Percy Maruwa Chimwamurombe, Buhlebenkosi Fuyane, Kayini Chigayo, Julien Lusilao. Comparative Nutritional Analysis of Tylosema esculentum (Marama Bean) Germplasm Collection in Namibia. Journal of Food and Nutrition Sciences. Vol. 8, No. 4, 2020, pp. 74-80. doi: 10.11648/j.jfns.20200804.11

Received: May 2, 2019; Accepted: July 1, 2019; Published: June 28, 2020

\begin{abstract}
Malnutrition is a medical condition caused by an unbalanced diet, typically characterised by stunting and wasting in children. Malnutrition causes approximately a third of all deaths in children between 0-59 months mostly in developing countries. In Namibia, 24\% of children under the age of 5 years are stunted while $6.2 \%$ are wasted. Tylosema esculentum, commonly known as marama bean is an underutilised legume of high nutritious value. Indigenous to Namibia, marama bean seeds have comparably high protein and lipid content. Marama bean is an appealing crop to Namibia in particular due to its low cultivation demands as it grows in sandy soils with minimal water requirements and no need for fertilisers. Ten accessions of marama bean seeds were analysed for their nutritional composition. The results indicate that ash content was found ranging between $2.13 \%$ and $3.46 \%$. Minerals analysed were calcium, iron, magnesium, phosphorus and zinc. Their range of concentrations were $750.1-2306.2 \mathrm{mgkg}^{-1}, 53.9-322.4 \mathrm{mgkg}^{-1}, 1764.1-7415.0 \mathrm{mgkg}^{-1}, 4300.8-5267.9 \mathrm{mgkg}^{-1}$ and $^{3} 2.2-48.8$ $\mathrm{mgkg}^{-1}$ respectively with no significant difference in concentration among the ten accessions. Correlation analysis of the minerals within the accessions showed that the correlations between zinc-magnesium and zinc-phosphorus concentrations were significantly different as compared to the rest of the pairs for all accessions. When analysed, the maximum and minimum amounts of crude fat and carbohydrates were $29.9 \%-44.1 \%$ and $19.4 \%-39.0 \%$ respectively which were found to not have a significant difference. However, the protein analysis determined that there was a significant difference with PMBC2 (mean content $34.6 \%$ ) being the most significant accession. Therefore, PMBC2 was found to be the most suitable accession for crop development and domestication. This study's main contribution with respect to the domestication of marama bean was the identification of the most superior accession based on nutritional composition.
\end{abstract}

Keywords: Malnutrition, Marama Bean, Nutritional Composition, Biofortifier, Crop Domestication

\section{Introduction}

\subsection{Malnutrition}

Malnutrition is a medical condition that arises from an unbalanced diet characterised by two extremes of nutritiondependent health complications being undernutrition and over nutrition. Conditions most commonly associated with malnutrition are stunting (low height for age), wasting (low weight for height), underweight (low weight for age), and morbidity (excess weight) [1]. In cases where it goes untreated, conditions such as marasmus and kwashiorkor may arise resulting in a condition known as severe acute malnutrition [2]. It is estimated that as a result of it, one-third of all child and infant deaths in developing countries are due to malnutrition with African and Asian countries having the 
highest cases [3].

The causes of child malnutrition vary but are largely influenced by social, economic and cultural shortcomings. The most significant and constant cause is education level of the child's caregivers, observing that less educated mothers would most likely have malnourished children. Poor maternal health also contributes negatively to child health together with a low income in a family [3, 4]. However, the main signs and symptoms of malnutrition may also be linked to food insecurity and the absence of varieties of food choices [5].

\subsection{Effects of Malnutrition}

Prolonged malnutrition leads to long term mental and physiological ailments. Some of the common effects include protein-energy malnutrition (PEM), typically characterised by kwashiorkor or marasmus, and micronutrient deficiencies including deficiencies in iron, iodine, zinc and vitamin A [6]. Iron deficiency (ID) in particular is associated with poor neurodevelopment, retarded growth and impaired immune response increasing susceptibility to infections [7]. The effects of malnutrition alter the natural gut microbiota causing the diminution of Bifidobacterium longum in the gut among others, indicating severe acute malnutrition. If prolonged, death may occur [8, 9]. Secondary effects of malnutrition include developmental or intellectual delays and susceptibility to infections due to immune dysfunction which may contribute to lower chances of survival and increased risks of morbidity [10, 11]. Furthermore, malnutrition puts a physiological strain on children with cardiovascular and metabolic complications arising at later stages [12].

\subsection{Solutions to Malnutrition}

Clinical treatment options for malnutrition include treating symptoms which may require hospital admission (especially in cases of severe acute malnutrition), so that provision of nutrition rich food and counselling of caregivers is availed [2]. The first treatment choice is usually a nutrition-based intervention were the children are given nutrition-rich foods in order to restore balance. However, feeding programs may be unsuccessful in treating malnutrition in communities due to cultural factors among others [13]. Research, therefore, has gone into developing other ways to curb malnutrition since $24 \%$ of children in Namibia are stunted while $6.2 \%$ are exhibit signs of wasting. The studies include incorporating plant proteins into cereals and initiatives of providing seed material to poor communities and interactive workshops with farmers to encourage the farming of sustainable crops [14].

This research will be based on Tylosema esculentum, (Burchell) Schreiber, (marama bean) leguminous plant indigenous to Botswana, Namibia and South Africa with the ability to survive and thrive in arid conditions. It is known to grow in poor sandy soils with evident heat tolerance [15]. Marama bean is an underutilised food crop despite its nutritional and economic advantages. Marama bean contains an estimated $29-39 \%$ protein [16], significantly higher than soya bean and chickpea (which are estimated to contain approximately between $34.3-36.3 \%$ and $23 \%$ respectively) $[17,18]$. Therefore, this research will reference indigenous knowledge systems of the San and Otjiherero people of Namibia who have been known to use T. esculentum, known to them as ozombanui.

\section{Materials and Methods}

Marama bean (Tylosema esculentum) seeds from ten accessions were collected for nutritional analysis from the Otjozondjupa Region, Namibia. The ten accessions were chosen based early flowering, high number of seeds per pod and high number of seeds per plant. For each sample, the seeds were dehulled and ground to a flour to allow for ease of analysis. The macronutrients quantified were proteins and fats and carbohydrates, while micronutrients analysed were minerals (calcium, iron, magnesium, phosphorus and zinc using spectrophotometry and spectrometry).

A modified method for sample preparation was used [19]. Air dried marama been seeds were de-hulled using a hammer. They were stored in Ziploc bags at $-20^{\circ} \mathrm{C}$ to reduce the possibility of spoilage, moisture absorbance and to prevent oxidation. The samples were ground into a flour using a laboratory mill.

\subsection{Ash Content}

The determination of ash content in marama bean was done using marama bean cotyledons which were weighed at approximately $3.0 \mathrm{~g}$ each and placed in porcelain crucibles and incinerated at $500^{\circ} \mathrm{C}$ for $24 \mathrm{hrs}$ and then $650^{\circ} \mathrm{C}$ for $4 \mathrm{hrs}$ until there was no change in weight indicating complete removal of all organic material [20]. The crucibles and sample were weighed before and after ashing. Samples were treated in triplicates and determination of percentage ash was done following the equation below:

$$
\% \operatorname{Ash}(d r y)=\frac{M_{C+a}-M_{C}}{M_{c+s}-M_{C}} \times 100
$$

Were:

$\mathrm{M}_{\mathrm{c}+\mathrm{a}}=$ Mass of crucible + ash residue

$\mathrm{M}_{\mathrm{c}+\mathrm{s}}=$ Mass of crucible + sample

$\mathrm{M}_{\mathrm{c}}=$ Mass of empty crucible

\subsection{Crude Protein Analysis}

Crude protein determination was done using the LECO TruSpec $^{\circledR}$ Micro N-Nitrogen/Protein Analyzer (CHN628) following the Duma combustion method [21]. Approximately $140.0 \mathrm{mg}$ of each sample was weighed into tin foil cups. Results were determined as percentage crude protein.

\subsection{Mineral Analysis}

Approximately $300 \mathrm{mg}$ of sample was digested for calcium, iron, magnesium and zinc analysis using the PerkinElmer Titan MPS $^{\mathrm{TM}}$ Microwave system using a mixture of $\mathrm{HCl}$ and 
$\mathrm{HNO}_{3}(3: 1)$. The mineral analysis of the samples was carried out using a PerkinElmer ${ }^{\circledR}$ Optima $^{\mathrm{TM}} 8000$ Inductively Coupled Plasma Optical Emission Spectrometry (ICP-OES) instrument.

The analysis of phosphorus was done via a colorimetric technique using Hach ${ }^{\circledR}$ Lange DR6000 Benchtop Spectrophotometer following a method described by Agri Laboratory Association of Southern Africa (6.2.5) [22].

\subsection{Crude Fat Analysis}

Crude fat was determined after the method developed by Agri Laboratory Association of Southern Africa (6.2.5) [22].

\subsection{Carbohydrate Determination}

The total carbohydrate content was determined following the method described by Holse, Husted and Hansen [23].

$$
\begin{gathered}
\text { Carbohydrate content }=\text { Ash }+ \text { Crude Protein }+ \\
\text { Crude Fat }
\end{gathered}
$$

\subsection{Data Analysis}

The data collected were analysed using SPSS (Version 22). Parametric tests were done using one-way analysis of variance (ANOVA) while Kruskal Wallis was employed as the non-parametric test of choice. Probability was accepted at $\mathrm{p}<0.05$.

\section{Results}

\subsection{Ash Content}

The percentage of ash content was found to be between $2.13 \%$ and $3.46 \%$. Test for normality was done by means of the Shapiro-Wilk test. The data were not normally distributed $(p=0.002)$. The subsequent Kruskal Wallis test revealed no significant differences of ash percentages among the marama bean samples $\left(\chi^{2}=9.267 ; p=0.413>0.05\right)$.

\subsection{Crude Protein Content}

The data were subjected to the Shapiro-Wilk test for normality, which showed the data to be normally distributed $(\mathrm{p}=0.631>0.05)$. The maximum and minimum protein content observed from all accessions were $34.8 \%$ and $30.1 \%$ respectively. To determine significance, one-way ANOVA was performed. The results showed that a statistically significant difference among samples with respect to protein content $(\mathrm{p}<0.001)$. A Tukey post hoc test revealed that the highest mean difference was observed between PMBC2 and PMBC8 $(p<0.001)$. Therefore, accession PMBC2 had the highest content of crude protein.

\subsection{Mineral Concentration}

The minerals concentrations (in $\mathrm{mgkg}^{-1}$ ) are shown in Table 2. The difference between the highest and lowest mean concentrations (being from PMBC7 and PMBC9 samples) was $47.3 \%$, while the mean concentrations of phosphorus had a $19.6 \%$ difference with $\mathrm{PMBC} 2$ having the maximum mean concentration and $\mathrm{PMBC} 10$ having the lowest. However, magnesium had the largest percent difference of means of 79.9\% (PMBC3 and PMBC5).

Data obtained for calcium, magnesium, phosphorus and zinc concentrations were not normality distributed (Shapiro Wilk, $\mathrm{p}<0.05)$. Therefore, non-parametric treatments were applied to all data sets. The Kruskal Wallis Test was performed in order to determine significance. The $\mathrm{p}$ values for calcium, magnesium, phosphorus and zinc were 0.538 , $0.621,0.111$ and 0.961 respectively (therefore, $p>0.05$ ) in all cases. As a result of the Kruskal Wallis $H$ values of calcium, magnesium, phosphorus and zinc being noted as high $(p>0.05)$, it was revealed that there was no significant difference among the concentrations of the individual elements among the 10 accessions.

Iron concentrations values were first subjected to the Shapiro-Wilk test for normality, which was found to be normally distributed $(\mathrm{p}=0.598>0.05)$ and subsequently subjected to one-way ANOVA. The test revealed that there was no significant difference among the samples for the concentration of iron $(p=0.099>0.05)$. Marama bean from the accession labelled PMBC4 had the highest mean concentration of iron at $322.4 \mathrm{mgkg}^{-1}$ while the lowest recorded concentration was $53.9 \mathrm{mgkg}^{-1}$ from PMBC7.

\subsection{Crude Fat Content}

Data obtained from fat analysis was presented as a percentage of samples' weight. The mean crude fat content for all samples was $39.3 \%$, while the lowest fat content was $29.9 \%$ and the highest being $44.1 \%$ (Table 1). The ShapiroWilk test for normality showed that the data were not normally distributed and therefore the non-parametric test, Kruskal Wallis had to be applied to the data. The Kruskal Wallis $H$ test result was observed to be $\chi^{2}=22.934, p=0.006$ $(\mathrm{p}<0.05), \mathrm{df}=9$. This indicates that the data collected on the amount of crude fat in marama bean samples were significantly different.

\subsection{Carbohydrate Content}

Carbohydrate content was determined by using the difference from the total proximate content. Carbohydrate content determined ranged from $19.4 \%$ to $39.0 \%$ as shown in Table 1 . The Shapiro Wilk test for normality showed the data to be not normally distributed $(\mathrm{p}<0.001)$. Therefore, a nonparametric test (Kruskal Wallis) was applied to the data. The Kruskal Wallis $\mathrm{H}$ test results in indicated that there was a significant difference $\left(\chi^{2}=20.215, \mathrm{df}=9, \mathrm{p}=0.017\right)$ among the samples of marama bean accessions. The mean carbohydrate content for all marama bean accession was $25.1 \%$. 
Table 1. Concentrations of nutrients analysed.

\begin{tabular}{|c|c|c|c|c|c|c|c|c|c|}
\hline Sample & Ash (\%) & $\begin{array}{l}\begin{array}{l}\text { Calcium } \\
(\mathrm{mg} / \mathrm{kg})\end{array} \\
\end{array}$ & $\begin{array}{l}\text { Magnesium } \\
(\mathrm{mg} / \mathrm{kg})\end{array}$ & $\begin{array}{l}\text { Phosphorus } \\
\text { (mg/kg) }\end{array}$ & $\begin{array}{l}\text { Iron } \\
\text { (mg/kg) }\end{array}$ & $\begin{array}{l}\text { Zinc } \\
(\mathrm{mg} / \mathrm{kg})\end{array}$ & $\begin{array}{l}\text { Carbohydrate } \\
(\%)\end{array}$ & $\begin{array}{l}\text { Crude Fat } \\
(\%)\end{array}$ & $\begin{array}{l}\text { Protein } \\
(\%)\end{array}$ \\
\hline PMBC1 & 2.87 & 1503.866 & 3405.528 & 4580.480 & 90.306 & 46.152 & 24.57 & 39.86 & 32.70 \\
\hline PMBC1 & 3.01 & 1298.535 & 2883.221 & 4583.920 & 62.083 & 37.509 & 25.14 & 39.35 & 32.50 \\
\hline PMBC1 & 2.83 & 1070.856 & 2410.523 & & 37.999 & 30.854 & 24.78 & 39.59 & 32.80 \\
\hline PMBC1 & & 1819.630 & 2643.020 & & & 35.190 & & & \\
\hline PMBC1 & & 1807.900 & 2689.980 & & & 34.880 & & & \\
\hline РMBC2 & 2.28 & 2200.968 & 4860.110 & 5238.400 & 150.980 & 67.054 & 25.80 & 37.42 & 34.50 \\
\hline PMBC2 & 2.65 & 814.501 & 2528.307 & 5267.930 & 118.640 & 23.797 & 25.21 & 37.54 & 34.60 \\
\hline РMBC2 & 3.18 & 1316.585 & 3247.004 & & 75.334 & 38.912 & 24.22 & 37.80 & 34.80 \\
\hline PMBC2 & & 1360.990 & 2856.820 & & & 32.820 & & & \\
\hline PMBC2 & & 1355.220 & 2893.000 & & & 31.080 & & & \\
\hline РMBC3 & 2.77 & 2306.222 & 7415.043 & 4655.960 & 251.250 & 78.246 & 25.57 & 39.46 & 32.20 \\
\hline PMBC3 & 3.12 & 1039.001 & 2588.071 & 4739.110 & 67.452 & 36.647 & 25.98 & 39.00 & 31.90 \\
\hline PMBC3 & 2.89 & 1000.568 & 2428.520 & & 56.161 & 31.518 & 26.07 & 38.94 & 32.10 \\
\hline PMBC3 & & 1758.260 & 2523.390 & & & 35.130 & & & \\
\hline PMBC3 & & 1784.370 & 2656.410 & & & 34.980 & & & \\
\hline PMBC4 & 2.83 & 1263.368 & 2787.311 & 4613.930 & 247.493 & 45.120 & 24.76 & 39.91 & 32.50 \\
\hline PMBC4 & 3.18 & 1545.620 & 3415.185 & 4656.850 & 618.174 & 57.990 & 23.62 & 40.40 & 32.80 \\
\hline PMBC4 & 2.95 & 1076.069 & 2409.407 & & 101.500 & 30.124 & 24.14 & 40.01 & 32.90 \\
\hline PMBC4 & & 1809.320 & 2589.350 & & & 35.600 & & & \\
\hline PMBC4 & & 1861.580 & 2591.560 & & & 35.090 & & & \\
\hline PMBC5 & 2.99 & 1187.839 & 2459.578 & 4608.060 & 181.171 & 41.997 & 24.61 & 38.20 & 34.20 \\
\hline PMBC5 & 2.93 & 1037.333 & 2220.133 & 4591.990 & 56.307 & 27.141 & 24.59 & 38.28 & 34.20 \\
\hline PMBC5 & 3.11 & 1025.628 & 2231.216 & & 34.716 & 27.438 & 24.96 & 38.43 & 33.50 \\
\hline PMBC5 & & 1703.700 & 2701.520 & & & 35.190 & & & \\
\hline PMBC5 & & 1701.010 & 2808.890 & & & 35.690 & & & \\
\hline PMBC6 & 2.92 & 1094.300 & 2979.119 & 4375.900 & 57.000 & 34.688 & 24.70 & 40.78 & 31.60 \\
\hline PMBC6 & 2.83 & 1335.948 & 3505.163 & 4427.830 & 66.126 & 41.009 & 36.04 & 29.93 & 31.20 \\
\hline PMBC6 & 2.89 & 1013.237 & 2807.363 & & 57.240 & 33.170 & 25.77 & 40.34 & 31.00 \\
\hline PMBC6 & & 1185.120 & 2766.900 & & & 27.940 & & & \\
\hline PMBC6 & & 1172.280 & 2853.080 & & & 28.250 & & & \\
\hline PMBC7 & 3.03 & 1188.135 & 2720.970 & 4566.430 & 42.752 & 31.674 & 19.41 & 44.06 & 33.50 \\
\hline PMBC7 & 2.94 & 1288.481 & 3012.969 & 4574.050 & 53.621 & 35.746 & 23.48 & 40.28 & 33.30 \\
\hline PMBC7 & 2.84 & 1387.159 & 3051.758 & & 65.421 & 37.095 & 23.82 & 40.44 & 32.90 \\
\hline PMBC7 & & 1827.490 & 2756.490 & & & 32.890 & & & \\
\hline PMBC7 & & 1820.040 & 2798.760 & & & 33.930 & & & \\
\hline PMBC8 & 3.12 & 1061.378 & 2985.532 & 4300.810 & 112.983 & 34.422 & 24.89 & 41.89 & 30.10 \\
\hline PMBC8 & 3.10 & 1020.318 & 2833.174 & 4360.810 & 65.717 & 33.949 & 24.14 & 41.46 & 31.30 \\
\hline PMBC8 & 3.46 & 967.142 & 2787.033 & & 66.274 & 33.988 & 23.66 & 41.78 & 31.10 \\
\hline PMBC8 & & 1252.160 & 2715.170 & & & 28.610 & & & \\
\hline PMBC8 & & 1271.030 & 2754.520 & & & 30.990 & & & \\
\hline РMBC9 & 2.91 & 1106.277 & 2391.143 & 4497.600 & 48.976 & 28.406 & 25.89 & 38.20 & 33.00 \\
\hline PMBC9 & 2.13 & 1369.251 & 2964.160 & 4373.140 & 74.356 & 39.212 & 27.38 & 37.59 & 32.90 \\
\hline PMBC9 & 3.08 & 2015.383 & 4611.358 & & 102.791 & 57.399 & 25.20 & 38.92 & 32.80 \\
\hline РМBC9 & & 1732.080 & 2737.960 & & & 31.280 & & & \\
\hline PMBC9 & & 1700.840 & 2697.130 & & & 30.170 & & & \\
\hline PMBC10 & 2.95 & 1272.426 & 2865.124 & 4371.000 & 98.515 & 38.374 & 24.60 & 39.55 & 32.90 \\
\hline PMBC10 & 2.94 & 750.1082 & 1764.121 & 4412.600 & 46.200 & 20.313 & 25.19 & 39.57 & 32.30 \\
\hline PMBC10 & 3.28 & 1385.828 & 3118.590 & & 123.825 & 42.515 & 23.81 & 39.81 & 33.10 \\
\hline PMBC10 & & 1693.750 & 2789.220 & & & 29.750 & & & \\
\hline PMBC 10 & & 1716.650 & 2767.410 & & & 30.630 & & & \\
\hline
\end{tabular}

\section{Discussion}

Analysis of the different important nutrients of marama bean populations has been carried out on bean populations from 3 countries namely Botswana, Namibia and South Africa with the sole purpose of identifying populations with highest concentrations of various nutrients. The ash content of a crop is used to provide a percentage content by mass of minerals in samples of interest [24]. It reflects the total 
amount of minerals in a sample, however, it does not show the concentrations and is not selective of the minerals that are left, therefore, even toxic heavy metals (if present) are included in the ash mass [25].

\subsection{Ash Content}

The results for ash content were between $2.7 \%$ and $3.2 \%$, values consistent with previous studies on marama bean samples from Botswana, Namibia and South Africa where ash contents of $2.5 \%-3.7 \%$ have been reported [23]. The ash content of treated marama bean flour indicates similar values, although an increase in ash content was noted in partially or fully defatted marama bean flour. These treated marama bean flour samples had ash values between $2.7 \%$ and $2.9 \%$ for full fat marama bean flour to $4.2 \%$ and $4.7 \%$ for partially defatted flours with the higher values in each case being for unheated samples [19].

\subsection{Crude Protein Content}

The protein content of marama bean determined was found to be between $30.1 \%-34.8 \%$. These values correspond with a previous study that found the crude protein content to be between $29 \%$ - 38\% [27]. An analysis of 3 marama bean samples harvested between 2001 and 2004 found the crude protein content ranging between $34.0 \%$ and $36.9 \%$ with an average value of $35.2 \%$. The study found that the climate during the time the samples were collected had a lesser impact on nutritional composition compared to the seasonal influence on plant growth [26]. The protein content parallels closely to that of soya bean which has a protein content of approximately $37.7 \%$ with a range between $36.9 \%-40.1 \%$ [28]. Comparison of marama bean with soya bean shows that they fall within range of each other with marama bean falling short of soya bean by $2 \%$. Due to their high protein contents, both marama bean and soya bean are suitable candidates for nutrient supplements and food alternatives [27]. When compared with other legumes, it is observed that marama bean is superior to other commonly consumed legumes. Cowpea (Vigna unguiculata L. Walp) has a crude protein content range between 23.2 - 28.1\% while kidney beans or common beans (Phaseolus vulgaris) have an average crude protein content of $20.1 \%( \pm 0.52)$ [ 18,29$]$. Therefore, the protein content of marama bean accessions within this study compares favourably with other legumes with a crude protein content range of $30.1-34.8 \%$. Statistical analysis revealed that PMBC2 had the highest crude protein content of the marama bean accessions analysed.

\subsection{Mineral Content}

Marama bean, as an underutilised legume with great potential, is highly comparable to other legumes such as soybean and chickpea while peanuts are a common entrant as a nutritional source. Soybean is nutrient rich with significant values of the major minerals. The content of zinc and iron (essential trace elements) from one study on samples from Benin City, Nigeria were approximately $27.0 \mathrm{mgkg}^{-1}$ and
$164.0 \mathrm{mgkg}^{-1}$ respectively. Calcium, magnesium and phosphorus were found to be $3003.6 \mathrm{mgkg}^{-1}, 2582.4 \mathrm{mgkg}^{-1}$ and $6952.0 \mathrm{mgkg}^{-1}$ respectively [28]. Cowpeas have mineral values much less than that of soybean [29]. However, their mineral content is worth mentioning as cowpeas also provide significant amounts of nutrients and minerals. The content of calcium in cowpeas compared to that of soybean is significantly low with ranges between $0.1-0.2 \mathrm{mgkg}^{-1}$. The concentrations of magnesium and phosphorus in cowpeas are higher with ranges between $1856-2274.0 \mathrm{mgkg}^{-1}$ and $4625.0-$ $5924.0 \mathrm{mgkg}^{-1}$ respectively. Iron and zinc content ranged from $60.6-106 \mathrm{mgkg}^{-1}$ and 32.6-51.1 $\mathrm{mgkg}^{-1}$ [29]. It can be seen that in both legumes, soybean and cowpea, the most abundant macro element is phosphorus with a sharp contrast being observed in the amount of calcium which may be attributed to the type of crop and soil conditions [30].

The mineral content of marama bean is highly comparable to that of soybean. Calcium, in particular, was observed to range between 750.1-2306.2 $\mathrm{mgkg}^{-1}$. Though lower compared to the mean calcium content of soybean it was considerably higher than that observed in cowpea varieties. Unlike in soybean and cowpea tests, the highest concentration of any macro element observed in marama bean was magnesium were the minimum concentration observed was $1764.1 \mathrm{mgkg}^{-1}$ and the maximum was 7415 $\mathrm{mgkg}^{-1}$. Phosphorus concentration ranged from 4300.8$5267.9 \mathrm{mgkg}^{-1}$, the lowest values observed among the three legumes mentioned in this section, the highest being observed in soybean. Compared to soybean and cowpea, mean iron concentrations in marama bean were lower to that of soybean. It should be noted that there was a $1666 \%$ difference between the lowest and highest concentrations of iron in marama bean alluding to the difference observable between accessions of a single plant species. The mean zinc concentrations were also higher in marama bean compared to both soybean and cowpea. Museler and Schonfeldt [26] when analysing marama bean seeds from Namibia and Botswana found that the mean concentrations for zinc and calcium were $62 \mathrm{mgkg}^{-1}$ and $2410.0 \mathrm{mgkg}^{-1}$ respectively, values close to double of mean concentrations determined in this study. However, the concentrations of iron, phoshorus and magnesium (39.5 mgkg ${ }^{-1}, 4540.0 \mathrm{mgkg}^{-1}$ and $2745.0 \mathrm{mgkg}^{-1}$ respectively) in the same study were lower than those determined in this study with the greatest difference being observed in the concentrations of iron.

The values of mineral content in marama bean indicate a strong similarity compared to data collected on varieties from Botswana (BO0603), Namibia (NA0701) and South Africa (SA0703) shown in Table 2 [23]. Both iron and zinc concentrations from PMBC samples (Namibia germplasm collection) were the highest in comparison to the other samples analysed from Botswana, Namibia and South Africa in a past study, an indication of the superiority of marama bean accessions in that respect [23]. The table also includes the values observed for accession PMBC2 which contained the highest protein content. 
Table 2. Mineral content ranges $\left(\mathrm{mgkg}^{-1}\right)$ of marama bean varieties and marama bean accessions.

\begin{tabular}{llllll}
\hline Mineral & NA0701* & BO0603* & SA0703* & PMBC & PMBC2** \\
\hline $\mathrm{P}$ & $4050-4576$ & $3307-3383$ & $5488-5594$ & $4301-5268$ & $5238-5268$ \\
$\mathrm{Mg}$ & $3580-3593$ & $2330-2647$ & $3712-3783$ & $1764-7415$ & $2528-4860$ \\
$\mathrm{Ca}$ & $937-1462$ & $2038-2176$ & $1313-1361$ & $750-2306$ & $814-2201$ \\
$\mathrm{Zn}$ & $31-39$ & $33-33$ & $38-39$ & $20-78$ & $24-67$ \\
$\mathrm{Fe}$ & $12-14$ & $13-14$ & $35-40$ & $35-618$ & $75-151$ \\
\hline
\end{tabular}

*Ranges of mineral content of marama bean samples analysed by Holse, Husted and Hansen [23].

**Ranges of mineral content of accession PMBC2.

\subsection{Crude Fat Content}

Comparing marama bean with other similar legumes, soybeans are the most nutritionally competitive legumes however, fat content of marama bean is typically twice that of soybeans. Soybeans are known to contain between $17.0 \%$ - $20.0 \%$ fats while marama beans previously analysed were found to contain between $32.0 \%-42.0 \%$ fats [23], values that correspond with the crude fat content determined within this study (29.9\% - 44.1\%). However, edible species seeds of Rynchosia have a far less crude fat content ranging between 3.3-4.4\% compared to marama bean accessions [31]. Compared to a previous analysis of marama bean seeds from Namibia and Botswana, (39.9\% and $40.2 \%$, respectively) [26], marama bean seeds analysed in this study had similar content values of $39.3 \%$. The difference in crude fat content may allude to the possible use of these legumes' plant oils in maintaining optimal cardiovascular health. Plant-based oils which are known to be low in saturated fats, thereby reducing and reversing the effects of coronary diseases, a trait most crucial to the health of all individuals [32].

\subsection{Carbohydrate Content}

The carbohydrate content determined was presented as an estimate from the proximate content of marama bean accessions. Moisture content was not considered in marama bean accession samples used in this research as the samples were dried before analysis, therefore, there were minuscule amounts of moisture. Carbohydrate content determined ranged from $19.4 \%$ to $36 \%$, with the highest calculated percentage being taken as an anomaly as it deviated from the previously determined maximum amount of carbohydrates in marama beans of $24 \%$. Prior studies have estimated the carbohydrate content of marama bean samples from Botswana, Namibia and South Africa to be between $19-24 \%$ [23]. This estimation found dietary fibre to be the most abundant within the carbohydrates. Another study found the mean

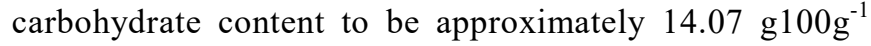
[26]. A calculated estimation much lower compared to the values obtained in this study.

\section{Conclusions and Recommendations}

It was found that phosphorus was the most abundant mineral while zinc had the lowest total concentration across all accessions. Analysis of the minerals (calcium, iron, magnesium, phosphorus and zinc), carbohydrates and crude fats did not find a significant difference among the accessions. Protein content, on the other hand, was observed to be (statistically) significantly different among the 10 accession samples. The greatest difference was observed between $\mathrm{PMBC} 2$ and $\mathrm{PMBC} 8$ with the former having a higher concentration of proteins. Therefore, this suggests that with respect to protein content accession PMBC2 is most suitable for crop development. It is recommended to investigate the nutritional composition of marama bean accessions in South Africa and Botswana where marama bean also grows indigenously. It is also suggested that a full vitamin analysis be done on the accessions done with special concentration on vitamin A and E. Trials on composite flours with marama bean added as a biofortifier are also recommended to be initiated with PMBC2.

\section{Acknowledgements}

We wish to thank the department of Natural and Applied Sciences and the department of Mining and Process Engineering at the Namibia University of Science and Technology, Mr Werner Gawanab and Mr Petrus Goagoseb for laboratory support and the support of Kirkhouse Trust. We would also like to thank Dr Ezekeil G Kwembeya for his assistance with data analysis.

\section{References}

[1] Ziba M, Kalimbira AA, Kalumikiza Z. Estimated burden of aggregate anthropometric failure among Malawian children. South African J Clin Nutr [Internet]. 2018; 31 (2): 20-3. Available from: https://doi.org/10.1080/16070658.2017.1387433

[2] Ghosh-Jerath S, Singh A, Jerath N, Gupta S, Racine EF. Undernutrition and severe acute malnutrition in children. BMJ. 2017; 359: j4877.

[3] Kalu RE, Etim KD. Factors associated with malnutrition among underfive children in developing countries: A review. Glob J Pure Appl Sci. 2018; 24 (1): 69.

[4] Akombi BJ, Agho KE, Hall JJ, Wali N, Renzaho AMN, Merom D. Stunting, wasting and underweight in Sub-Saharan Africa: A systematic review. Int J Environ Res Public Health. 2017; 14 (8): 1-19. 
[5] Motbainor A, Worku A, Kumie A. Stunting is associated with food diversity while wasting with food insecurity among underfive children in East and West Gojjam Zones of Amhara Region, Ethiopia. PLoS One [Internet]. 2015; 10 (8): 1-15. Available from: http://dx.doi.org/10.1371/journal.pone.0133542

[6] Bain LE, Awah PK, Geraldine N, Kindong NP, Sigal Y, Bernard N, et al. Malnutrition in Sub - Saharan Africa: Burden, causes and prospects. Vol. 15, Pan African Medical Journal. 2013. p. 1-9.

[7] Domello M, Braegger C, Campoy C, Colomb V, Decsi T. Committee on Nutrition : 2014; 58 (1): 119-29.

[8] Million M, Diallo A, Raoult D. Gut microbiota and malnutrition. Microb Pathog [Internet]. 2017; 106 (February): 127-38. Available from:

http://dx.doi.org/10.1016/j.micpath.2016.02.003

[9] Alou MT, Million M, Traore SI, Mouelhi D, Brah S, Alhousseini D, et al. Gut Bacteria Missing in Severe Acute Malnutrition, Can We Identify Potential Probiotics by Culturomics ? 2017; 8 (May): 1-17.

[10] Mehta NM, Corkins MR, Lyman B, Malone A, Goday PS, Carney L, et al. Defining pediatric malnutrition: A paradigm shift toward etiology-related definitions. J Parenter Enter Nutr. 2013; 37 (4): 460-81.

[11] Goudet S, Griffiths P, Bogin B, Madise N. Interventions to tackle malnutrition and its risk factors in children living in slums: a scoping review. Vol. 44, Annals of Human Biology. 2017. p. 1-10.

[12] Ramos C V, Dumith SC, César JA. Prevalence and factors associated with stunting and excess weight in children aged 05 years from the Brazilian semi-arid region. J Pediatr (Rio J) [Internet]. 2015; 91 (2): 175-82. Available from: http://dx.doi.org/10.1016/j.jped.2014.07.005

[13] Mas-Harithulfadhli-Agus AR, Hamid NA, Rohana AJ. Rural child malnutrition and unsuccessful outcome of food basket programme: does ethnicity matter? Ethn Heal [Internet]. 2018; 0 (0): 1-16. Available from: https://doi.org/10.1080/13557858.2018.1494820

[14] Temba MC, Njobeh PB, Adebo OA, Olugbile AO, Kayitesi E. The Role of Compositing Cereals with Legumes to Alleviate Protein Energy Malnutrition in Africa. Int J Food Sci Technol. 2016; 51 (3): 543-554.

[15] Cullis C, Kunert K, Vorster J, Chimwamurombe P, Barker N. Orphan Legumes Growing in Dry Environments: Marama Bean as a Case Study. Front Plant Sci. 2018; 9 (1199).

[16] Jackson JC, Duodu KG, Holse M, Lima de Faria MD, Jordaan $\mathrm{D}$, Chingwaru W, et al. The Morama Bean (Tylosema esculentum): A Potential Crop for Southern Africa. Adv Food Nutr Res. 2010; 61: 187-246.

[17] Bøhn T, Cuhra M, Traavik T, Sanden M, Fagan J, Primicerio R. Compositional differences in soybeans on the market: Glyphosate accumulates in Roundup Ready GM soybeans. Food Chem [Internet]. 2014; 153: 207-15. Available from: http://dx.doi.org/10.1016/j.foodchem.2013.12.054

[18] Qayyum MMN, Butt MS, Anjum FM, Nawaz H. Composition analysis of some selected legumes for protein isolates recovery. J Anim Plant Sci. 2012; 22 (4): 1156-62.

[19] Kayitesi E, De Kock HL, Minnaar A, Duodu KG. Nutritional quality and antioxidant activity of marama-sorghum composite flours and porridges. Food Chem. 2012; 131 (3): $837-42$.

[20] Enders A, Lehmann J. Comparison of Wet-Digestion and DryAshing Methods for Total Elemental Analysis of Biochar. Commun Soil Sci Plant Anal. 2012; 43 (7): 1042-52.

[21] Mihaljev Ž, Jakšić S, B Prica N, N Ćupić Ž, Baloš M. Comparison of the Kjeldahl method, Dumas method and NIR method for total nitrogen determination in meat and meat products. J Agroaliment Process Technol. 2015; 21 (April 2017): 365-70.

[22] Agri Laboratory Association of Southern Africa. Handbook on Feeds and Plant Analysis. 2nd ed. Palic P, Claassens AS, Collier J, Loock A, Hattingh D, editors. Agri Laboratory Association of Southern Africa; 2007.

[23] Holse M, Husted S, Hansen Å. Chemical Composition of Marama Bean (Tylosema esculentum) - A Wild African Bean with Unexploited Potential. J Food Compos Anal. 2010; 23: 648-57.

[24] Jhaumeer Laulloo S, Bhowon MG, Soyfoo S, Chua LS. Nutritional and Biological Evaluation of Leaves of Mangifera indica from Mauritius. J Chem. 2018; 1-9.

[25] Zhou H, Yang WT, Zhou X, Liu L, Gu JF, Wang WL, et al. Accumulation of heavy metals in vegetable species planted in contaminated soils and the health risk assessment. Int $\mathrm{J}$ Environ Res Public Health. 2016; 13 (3).

[26] Museler DL, Schonfeldt H. The Nutrient content of the marama bean. Agricola. 2006; $2-8$.

[27] Amonsou EO, Taylor JRN, Beukes M, Minnaar A. Composition of marama bean protein. Food Chem [Internet]. 2012; $130 \quad$ (3): 638-43. Available from: http://dx.doi.org/10.1016/j.foodchem.2011.07.097

[28] Etiosa O, Chika N, Benedicta A. Mineral and Proximate Composition of Soya Bean. Asian J Phys Chem Sci. 2018; 4 (3): $1-6$

[29] Gerrano AS, Jansen van Rensburg WS, Venter SL, Shargie NG, Amelework BA, Shimelis HA, et al. Selection of cowpea genotypes based on grain mineral and total protein content. Acta Agric Scand Sect B Soil Plant Sci. 2019; 69 (2): 155-66.

[30] Marles RJ. Mineral nutrient composition of vegetables, fruits and grains: The context of reports of apparent historical declines. J Food Compos Anal [Internet]. 2017; 56: 93-103. Available from: http://dx.doi.org/10.1016/j.jfca.2016.11.012

[31] Kalidass C, Mohan VR. Biochemical composition and nutritional assessment of selected under-utilized food legume of the genus rhynchosia. Int Food Res J. 2012; 19 (3): 977-84.

[32] Sanchez A, Mejia A, Sanchez J, Runte E, Brown-Fraser S, Bivens RL. Diets with customary levels of fat from plant origin may reverse coronary artery disease. Med Hypotheses [Internet]. 2019; 122 (October 2018): 103-5. Available from: https://doi.org/10.1016/j.mehy.2018.10.027 